\title{
PENELUSURAN HISTORIS \\ MELALUI VISUAL BANGUNAN ART DECO. SEBUAH UPAYA BUFFER KUALITAS WAJAH KOTA KE ERA KOMERSIALISASI DI MALANG
}

\author{
Imam Santoso* \\ Jurusan Arsitektur, Fakultas Teknik, Universitas Merdeka Malang \\ *imasant_ars@yahoo.com
}

\begin{abstract}
ABSTRAK
Fenomena perkembangan pembangunan kota hingga saat ini belum beranjak dari era komersialisme sebagai bagian dari modernisme kehidupan kota termasuk Indonesia. Apapun yang bernilai komersial menjadi alasan yang dianggap cukup kuat untuk membangun yang baru dan membongkar yang lama (yang bernilai historis). Fenomena yang sama tidak ada kecuali terjadi di kota Malang.

Kota Malang memiliki karakteristiknya sendiri sebagai salah satu kota koloni Belanda. Sejak tahun 1914 kota Malang direncanakan dengan sangat baik oleh arsitek Belanda Thomas Karsten. Perkembangan arsitektur kota Malang pada masa kolonial tidak lepas dari pengaruh arsitektur modern yang sedang melanda pada waktu itu. Tak terkecuali pada era 1920 dan 1930 an, saat berkembangnya style Art Deco di Eropa. Dalam beberapa kasus bangunan kolonial di kota Malang, karakteristik Art Deco masih eksis dan relevan dengan perkembangan jaman hingga saat ini. Sebagai contoh adalah bangunan yang berada di kawasan Kayutangan.

Art Deco sebagai semangat berarsitektur (walaupun belum ada penelitian tentang hal ini), dapat dirasakan hingga saat ini. Gaya minimalis yang banyak digemari saat ini diyakini oleh sebagian arsitek di Indonesia memiliki kekuatan rancangan Art Deco. Salah satu ciri streamline hasil fabrikasi serta teknik pembentukannya dipandang sukses membentuk citra masa lampau sekaligus masa kini. Style Art Deco memberi peran yang cukup besar bagi wajah kota dan kontribusi bagi kepariwisataan hingga dikenal hingga saat ini. (Tinniswood: 2002, Cherwinsky: 1981). Tulisan ini dimaksudkan untuk mengeksplorasi karakteristik visual bangunan Art Deco di kawasan Kota Malang yang sangat diperlukan untuk menjaga performance wajah kota, dalam rangka melestarikan pusaka kota.
\end{abstract}

Kata kunci: visual bangunan, Art Deco, komersialisasi, performance wajah kota.

\section{PENDAHULUAN}

Fenomena perkembangan pembangunan kota hingga saat ini belum beranjak dari era komersialisme sebagai bagian dari modernisme kehidupan kota di Indonesia. Apapun yang bernilai komersial menjadi alasan yang dianggap cukup kuat untuk membangun yang baru dan membongkar yang lama. Fenomena yang sama tidak ada kecuali terjadi di kota Malang. Dalam kurun waktu singkat telah dibangun puluhan fasilitas komersial di kawasan kota Malang baik berupa ruko, kantor, hotel, dsb yang didirikan dengan mengabaikan aspek keselarasan dan kesinambungan kualitas wajah kota. Bahkan sebagian besar cenderung melanggar aturan-aturan teknis pembangunan yang ditetapkan 
pihak Pemkot. Di sisi lain pelestarian bangunan merupakan salah satu upaya untuk meningkatkan performansi kota terutama di sektor pariwisata. Kota Malang yang memiliki julukan kota peristirahatan semestinya dapat mengambil peluang dalam bentuk upaya pelestarian wajah kota tersebut

Secara ideal dari perkembangan kehidupan perkotaan seharusnya memiliki visi yang kuat untuk mendorong pembangunan yang berkelanjutan. Salah satu yang dapat diupayakan adalah pelestarian pusaka kota. Perangkat aturan berupa Undang-undang sudah ada yaitu UU No 5 tahun 1992 tentang Benda Cagar Budaya yang dimaksudkan untuk melindungi pusaka yang berbentuk fisik. Beberapa daerah menerbitkan Perda dan Keputusan gubernur atau Walikota/Bupati untuk melindungi bangunan yang bersejarah atau bernilai tinggi. Namun demikian berbagai aturan yang ada banyak dilanggar baik oleh masyarakat maupun pemerintah sendiri.

Tulisan ini dimaksudkan sebagai eksplorasi awal bangunan yang memiliki gaya Art Deco. Beberapa bangunan yang diambil sebagai kasus pengamatan dan analisis adalah bangunan Toko Avia, bangunan PLN, rumah tinggal di jalan Semeru, Bank Commonwealth, dan bangunan Pit Stop.

\section{KAJIAN PUSTAKA}

\section{Pusaka Kota}

Upaya pelestarian dikatakan oleh Adishakti (2004) merupakan suatu usaha pembangunan yang berbasis budaya ekologi-masyarakat secara menyeluruh, komprehensif, dan berkelanjutan. Kendala terbesar yang menyebabkan tidak terkelolanya pelestarian pusaka kota dengan baik adalah tingkat kesadaran dan apresasi masyarakat kota yang sangat rendah terhadap eksistensi fisik yang bukan sekedar bernilai historis. Kesadaran yang kurang bahwa setiap kota terutama yang memiliki nilai historis (termasuk kota Malang) perlu menunjukkan identitas masing-masing. Identitas tersebut secara visual akan tercermin melalui wajah kota yang merefleksikan bentuk akhir dari sebuah pengelolaan kota dan kehidupan masyarakat.

Kegiatan pelestarian diyakini merupakan salah satu alat untuk mengelola wajah kota yang tetap menunjukkan kesinambungan dengan sejarah namun mampu memberikan pelayanan kepada masyarakat dalam memenuhi kehidupannya yang selalu berkembang. termasuk disini upaya revitalisasi yang tidak hanya sekedar mempercantik ruang tetapi justru mengembalikan vitalitas manusia dan lingkungannya Sejalan dengan semangat untuk menumbuh kembangkan kesadaran pelestarian pusaka kota, sangat perlu dilakukan studi yang lebih mendalam dan rinci dalam lingkup akademis sekaligus membuka jalan upaya-upaya pelestarian yang lebih memasyarakat. Salah satunya adalah memperdalam keanekaragaman style/gaya bangunan yang bernilai historis.

\section{Art Deco Dalam Istilah}

Art Deco adalah istilah yang populer di Indonesia pada tahun 1960-an dan merujuk pada karya arsitektur dalam konteks suatu gaya/style dekoratif pada bangunan. Gaya Art Deco muncul di dekade 20-an dan 30-an sebagai reaksi penolakan modernis atas gaya Art Nonveau dengan karakteristik bentuk-bentuk melingkar-lingkar dan geometris simetris (Trinniswood, 2002). Art Deco sebagai istilah dalam kenyataannya tidak terbatas pada karya-karya arsitektur bangunan saja, melainkan pada berbagai macam karya/produk seni terutama interior. Art Deco populer di Indonesia melalui orang-orang Belanda yang datang pada masa Kolonial (khususnya para arsitek penganut pada jaman itu), tak terkecuali yang berada di kota Malang (Handinoto, 1996). Para arsitek yang berkarya di Indonesia banyak dipengaruhi oleh 
karya Frank Lloyd Wright. Beberapa karya-karya Wright memiliki kesamaan dengan cara pandang yang dicitrakan oleh style Art Deco. (Poerwoningsih, 2004)

Art Deco sebagai semangat berarsitektur (walaupun belum ada penelitian tentang hal ini), dapat dirasakan hingga saat ini. Gaya minimalis yang banyak digemari saat ini diyakini oleh sebagian arsitek di Indonesia memiliki kekuatan rancangan Art Deco. Salah satu ciri streamline hasil fabrikasi serta teknik pembentukannya dipandang sukses membentuk citra masa lampau sekaligus masa kini. Di beberapa negara di Eropa (Perancis, Belanda, dsb), dan Amerika ( Miami), style Art Deco memberi peran yang cukup besar bagi wajah kota dan kontribusi bagi kepariwisataan hingga dikenal hingga saat ini. (Tinniswood: 2002, Cherwinsky: 1981).

\section{Nilai dan Makna Penting Style Art Deco}

Art Deco merupakan sebuah gaya yang mempengaruhi dunia arsitektur, interior dan aspek kehidupan lainnya pada masa paruh awal abad ke-20. Istilah Art Deco pertama kali digunakan oleh Bevis Hiller dalam buku tentang seni Dekoratif pada tahun 1968, yang ditujukan untuk produk seni dekoratif dan desain produk industri yang dihasilkan di antara kedua Perang Dunia (Duncan dalam Dibyo Hartono, 2005)

Dalam perkembangannya elemen dekoratif dalam arsitektur mulai terlihat sejak awal abad ke 20, di mana dalam periode akhir Art Nonvean sudah mulai memperlihatkan digunakannya garis-garis lengkung dari tema dekoratif tanam-tanaman memperlihatkan ciri garis-garis yang semakin keras dan tegas, serta pola dekoratif yang tidak simetris lagi. Oleh karenanya masih menurut Duncan, dalam buku 'American Art Deco' mengatakan bahwa Art Deco adalah merupakan kelanjutan dari Art Nouveau.
Art Deco dalam konsepsi Arsitektur sangat sukar didefinisikan (Hartono, 2006). Padahal sesungguhnya sebagai sebuah konsep perkembangan arsitektur merupakan sebuah gaya yang sangat kaya mengacu pada berbagai gaya seni dekoratif tradisional maupun bentuk dekorasi modern. Kini banyak dijadikan sebagai perbendaraan berbagai gaya dalam gerakan arsitektur modern, termasuk di Indonesia.

Sementara Lukito (2006) menyatakan bahwa Apa yang menjadi karakteristik Art Deco sebenarnya adalah sebuah modernisasi dari gaya dan tema sebelumnya. Karenanya kita mengenal Art Deco sebagai seni eklektik yang bisa menampilkan pengaruh dari berbagai tempat baik modern maupun vernakular. Elemen modern dalam Art Deco merupakan juga polapola dan material yang mengisyaratkan kekuatan dari mesin dan bahkan inspirasi bentuk alam seperti bunga dan matahari. Namun dapat dipastikan hal yang paling penting adalah mereka semua memiliki aturan geometris dan format yang sederhana.

Masih menurut Lukito, Art Deco merupakan sebuah reaksi terhadap Art Nouveau yang memiliki karakter lengkungan menerus dan terinspirasi bentuk-bentuk alam. Karenanya karakteristik dari Art Deco adalah selalu menggunakan bentuk-bentuk geometris baik angular maupun simetris. Lengkungan yang terdapat pada Art Deco pada perkembangan selanjutnya tidak sama dengan Art Nouveau karena kita dapat terus mendapatkan kesinambungan garis-garis vertikal yang dipadukan pada bagian yang melengkung.

\section{Perkembangan Style Art Deco di Indonesia}

Pengaruh Art Deco di Indonesia berasal dari arsitek Belanda pada masa kolonial. Pada tahun 1917 tumbuh gerakan arsitektur modern seperti Amsterdamse School dan De Stijl. Dalam perkembangannya, melalui beberapa arsitek Belanda yang berkarya di Indonesia, konsepsi dekoratif dari fasade bangunan 
Art Deco' Amsterdamse School' memperlihatkan kesamaan ekspresi visual dengan hasil Art Deco di kota Bandung khususnya tahun 1920-an. Beberapa bangunan memperlihatkan kesamaan pola-pola ornamentasi geometris dan patung manusia pada fasade bangunan yang hampir sama (Hartono, 2005). Gedung Sate (1914), gedung Jaarbeurs (1920), dan Villa Isola merupakan karya C.P.Wolff Schoemaker ,salah stu arsitek Belanda yang mengaplikasikan konsepsi dekoratif pada karya-karyanya tersebut.

Dalam perkembangannya banyak unsur-unsur dalam gaya Art Deco yang dipengaruhi oleh aliran arsitektur modern yaitu dengan pemakaian sistem modular yang memudahkan produksi dan pemasangan seperti kusen, plafon, dan bahan-bahan finishing lainnya. Pemakaian elemen dekoratif dalam arsitektur dilakukan secara total dengan mengambil suatu tema yang mencerminkan Art Deco yang konsisten sehingga mudah dipahami. Gaya Art Deco mudah diterima di Indonesia karena mengandung banyak hiasan dan ukiran yang sebelumnya banyak terdapat dalam khasanah bentuk arsitektural di Indonesia (Candi dan rumah tradisional). Ciri lainnya adalah penggunaan sistem struktur yang modular dengan pemakaian warna-warna asal material (ciri Art Deco tropis) berbeda dengan gaya arsitektur Art Deco tropis yang ada di Miami yang lebih ekspresionis karena unsur pantainya. (Lukito, 2005).

\section{Tipologi sebagai sebuah Pendekatan Pemerian Fasade (Wajah) Bangunan}

Untuk memahami suatu bentuk dan ruang dalam arsitektur terdapat 3 (tiga) komponen struktural yang dapat dikaji yaitu Topologi, Tipologi dan Morfologi. Topologi berkaitan dengan tatanan ruang (spatial order) dan pengorganisasian ruang (spatial organization), terkait dengan tempat yang abstrak. Sementara Tipologi menunjuk pada konsep dan konsistensi yang memudahkan orang lain mengenal bagian-bagian arsitektur, serta merupakan ilmu tentang makna suatu produk (Moneo, 1978). Morfologi berkaitan dengan kualitas figural suatu ruang dalam konteks wujud pembentuk ruang yang dapat dibaca melalui pola dan hubungan

Fasade merupakan elemen arsitektural yang paling esensial untuk mengkomunikasikan fungsi dan kepentingan bangunan. Fasade bukan hanya, kebutuhan alami" yang ditentukan oleh organisasi ruang di baliknya, akan tetapi fasade berbicara tentang situasi kultural pada saat didirikannya bangunan. Fasade juga berbicara tentang masyarakat dari bangunan tersebut, yang menunjukkan identitas kelompok suatu komunitas. (Krier, 1998)

Bertolak dari pengertian tersebut, maka pembahasan fasade pada bangunan dengan style Art Deco ini menjadi signifikan. Komposisi fasade terdiri dari elemen-elemen fungsional ( seperti jendela, pintu, sunscreen, kanopi, atap, dsb) yang dibangun dengan pertimbangan kesatuan harmoni atas proporsi, ritme vertikal horisontal, material/bahan penyusunnya, warna dan tekstur, serta elemen dekoratif lainnya.

\section{PEMBAHASAN}

Pengaruh Gaya Art Deco di Kota Malang dibawa oleh salah satu arsitek Belanda yang banyak berkarya di Indonesia yaitu Thomas Karsten. Setidaknya Karsten merupakan salah satu arsitek Belanda yang membawa pengaruh de Stijl yang berperan besar dalam Arsitektur Indis yang selanjutnya memberi pengaruh pada Gaya Art Deco. Beberapa bangunan yang bergaya Art Deco sebut saja Toko Oen, Stasiun Kota Malang, Gedung PLN, Toko Avia, dan sejumlah rumah tinggal.

Kota Malang memiliki karakteristiknya sendiri sebagai salah satu kota koloni Belanda. Sejak tahun 1914 kota Malang direncanakan dengan sangat baik oleh arsitek 
Belanda Thomas Karsten. Perkembangan arsitektur kota Malang pada masa kolonial tidak lepas dari pengaruh arsitektur modern yang sedang melanda pada waktu itu. Tak terkecuali pada era 1920 dan 1930 an, saat berkembangnya style Art Deco di Eropa. Dalam beberapa kasus bangunan kolonial di kota Malang, karakteristik Art Deco masih eksis dan relevan dengan perkembangan jaman hingga saat ini. Sebagai contoh adalah bangunan yang berada di kawasan Kayutangan.
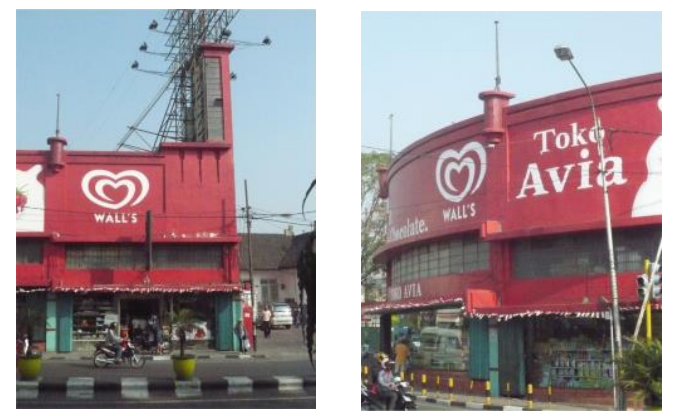

Gambar 1. Toko AVIA di Jalan Basuki Rachmat Sumber: Photo pribadi 2008
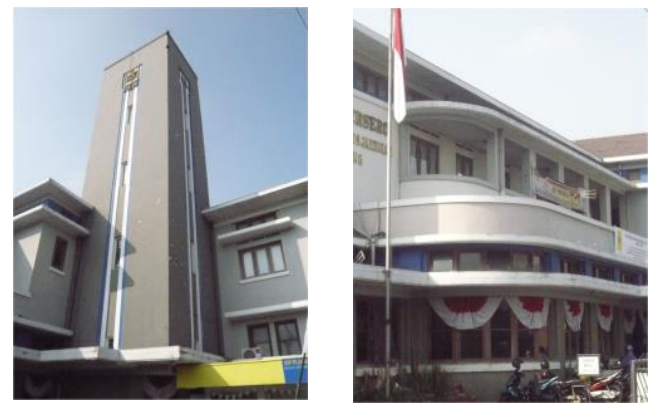

Gambar 1. Toko AVIA di Jalan Basuki Rachmat Sumber: Photo pribadi 2008
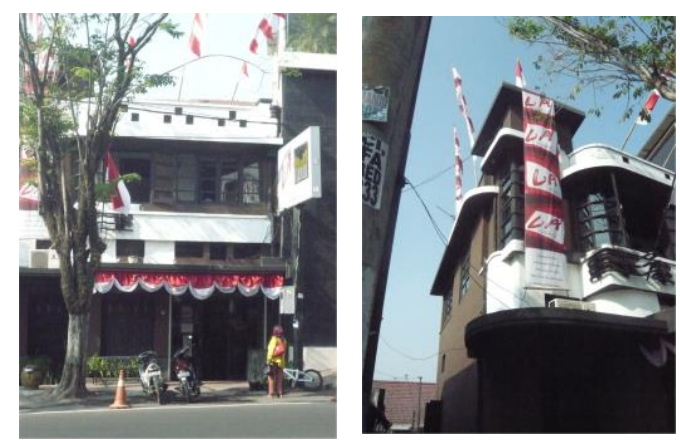

Gambar 3. Rumah Tinggal di Jalan Semeru 31 Sumber: Photo pribadi 2008
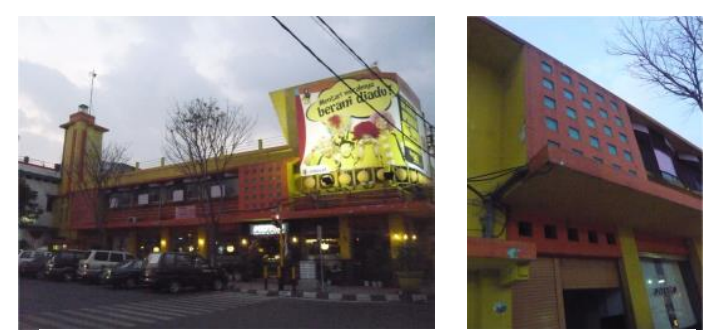

Gambar 5. Pit Stop , Perempatan Jl. Basuki Rahmat dan Jl. Semeru Sumber: Photo pribadi 2008
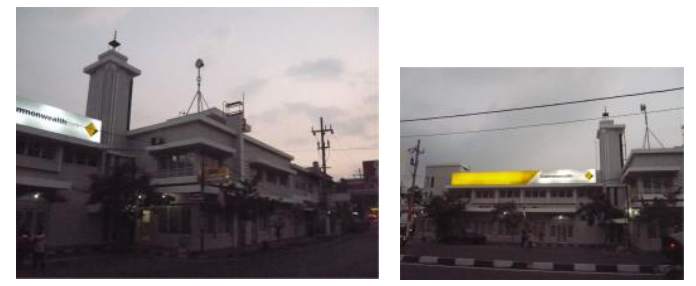

Gambar 4. Bank Commonwealth Perempatan Jl. Basuki Rachmat dan Jl. Semeru Sumber: Photo pribadi 2008

Ciri lengkungan dekoratif terdapat pada bangunan Toko Avia, PLN, Rumah jalan Semeru. Ciri elemen 
penyelesaian sudut berupa elemen vertikal terdapat pada semua bangunan sampel. Elemen vertikal pada bangunan PLN terlihat sangat dominan dalam posisi dan dimensi. Sementara untuk bangunan Toko Avia, elemen vertikat terlihat dominan karena jumlah dan irama. Elemen kanopi di atas jendela tedapat pada seluruh bangunan sampel dengan beberapa varian umlah susunan jendela dan jumlah lapisan kanopi.

\section{Studi Sejenis pada Bangunan Historis}

Studi yang dilakukan terhadap obyek bangunan bernilai historis telah banyak dilakukan, dokumendokumen kompilasi, inventarisasi dari bangunanbangunan tersebut sudah banyak diperoleh. Hampir seluruh kota yang bernilai historis sebagai kota yang pernah menjadi koloni jaman penjajahan telah menjadi obyek penelitian, sebagai misal Jakarta, bandung, Yogyakarta, Semarang, Surabaya, dan tak terkecuali kota Malang. Studi-studi arsitektural yang mendalam dan bersifat sangat detail tentunya lebih banyak ditentukan oleh kapasitas konteks lokasi dan waktu, sehingga setiap studi semacam itu pasti akan menghasilkan keragaman yang berbeda dari aspek substansi walaupun dalam aspek formatif yang sama serta dari metodologi penelitian yang sama (sebagian besar adalah metodologi kualitatif dengan pendekatan positivistik).

Salah satu studi yang pernah dilakukan dan memiliki keberlakuan yang bersifat lebih luas adalah Studi Konsep Panduan Tampilan Bangunan Baru di Kawasan Konservasi Melalui Pendekatan Kontekstual (Malik, 1991). Penelitian ini menyinggung pada konservasi karakter fasade bangunan dan bertujuan mencari pola umum bagi bangunan baru. Penelitian ini dilakukan di kawasan-kawasan kota lama.

Penelitian arsitektural yang lain adalah yang dilakukan oleh Yulita (1995) berjudul Sistem Visual Kawasan Pusat Kota Lama. Penelitian ini berusaha mengungkapkan kaitan komponen visual bangunan yang satu dengan bangunan yang lain yang membentuk suatu sistem visual. Disamping itu juga mengungkapkan tanda-tanda visual yang menentukan komponen tersebut merupakan bagian dari suatu sistem visual yang nantinya dapat digunakan untuk dasar mempertimbangkan komponen yang harus dipertahankan dan yang dapat dikembangkan untuk kepentingan lain. Kedua penelitian tersebut menggunakan populasi dan unit sample berupa obyek kawasan dan bangunan dalam membangun konsep arsitektural/visual bangunan.

Penelitian lain dilakukan terhadap obyek kajian berupa penggalan koridor jalan sebagai suatu entitas ruang luar urban seperti yang dilakukan dalam judul penelitian Karakteristik Visual Koridor Jalan Pemuda Semarang (Mulyani, 1996). Penelitian ini adalah penelitian yang menggunakan populasi dan sampel responden dalam membangun konsep karakteristik visual sebagai bentuk penilaian terhadap lingkungan (environmental assesment) dalam teori perilaku.

\section{KESIMPULAN DAN SARAN}

Wajah bangunan kota Malang memiliki sebagian dari karakteristik Art Deco yang tercermin pada komposisi elemen fasade antara lain jendela, pintu, sunscreen, kanopi, atap, dsb. Elemen-elemen tersebut masih terlihat menarik dan mampu memberi warna pada lingkungannya. Mendasarkan pada wacana Art Deco sebagai semangat berarsitektur, tentunya aset-aset bangunan yang masih tersisa di Kota Malang menjadi sangat berharga untuk dikaji.

Penelitian yang dilakukan terhadap obyek bangunan dan kawasan di kota Malang telah banyak dilakukan, antara lain dalam bentuk penelitian dosen maupun mahasiswa, namun dalam bentuk unit penelitian arsitektural yang mikro, masih belum banyak 
dilakukan. Bangunan Art Deco yang dimiliki kota Malang perlu mendapat perhatian berupa status cagar budaya.

\section{REFERENSI}

Burden, Ernest. 1995. Elements of Arcbitectural Design; A Visual Resource. Van Nostrand Reinhold. New York.

Cerwinske, Laura.1981. Tropical Deco, The Architecture and Design of Old Miami Beach, Rizzoli, New York.

Handinoto. 1996. Perkembangan Kota \& Arsitektur Kolonial Belanda di Malang. Penerbit Andi. Yogyakarta.

Krier, Rob. 1988. Architectural Composition. Academy Edition. London.

Malik, A. 1991. Studi Konsep Panduan Tampilan Bangunan Baru di Kawasan Konservasi Melalui Pendekatan Kontekstual. Tesis S-2 Arsitektur ITB. Bandung.

Moneo, R. 1978. On Typology, oppositions. MIT Press

Muhadjir, Noeng. 1996. Metodologi Penelitian Kualitatif. Penerbit Rake Sarasin. Yogyakarta.

Mulyani, Tri Hesti. 1996. Karakteristik Visual Koridor Jl. Pemuda Semarang. Tesis S-2 Arsitektur UGM. Yogyakarta

Poerwoningsih, Dina. 2004. Penjajaran Arsitektur Kolonial dan Arsitektur Karya Frank Lloyd Wright, penjelajaban disain yang belum selesai, Jurnal Arsitektur" Mintakat".Malang.

Santoso, Imam. 2006. Pengaruh Gaya Hiasan Dekoratif Pada Bangunan Di Kota Malang . ART DECO sebagai ART MODERNE. GKAK Jurusan Arsitektur FT. Universitas Merdeka Malang

Tinniswood, Adrian. 2002. The Art Deco House; AvantGarde Houses of the 1920s and 1930s. Octopus Publishing Group Ltd. London.

Yulita, Titik. 1995. Sistem Visual Kawasan Pusat Kota Lama, Tesis S-2 Arsitektur UGM, Yogyakarta
2005. Art Deco di Indonesia, A Life Style. Proseding Seminar Nasional. Universitas Tarumanegara. Bandung 